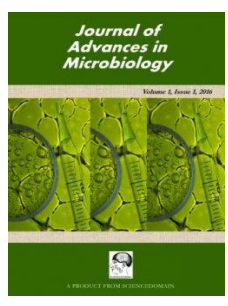

\title{
Solid Substrate Fermentation of African Bush Mango (Irvingia gabonensis) Seeds
}

\author{
Kehinde Tope Adegbehingbe ${ }^{1^{\star}}$, Bartholomew Saanu Adeleke ${ }^{2}$ and Soji Fakoya ${ }^{3}$ \\ ${ }^{1}$ Department of Microbiology, Adekunle Ajasin University, Akungba Akoko, Nigeria. \\ ${ }^{2}$ Department of Microbiology, Federal University of Technology, Akure, Nigeria. \\ ${ }^{3}$ Department of Biological Sciences, Ondo State University of Science and Technology, Okitipupa, \\ Nigeria.
}

\section{Authors' contributions}

This work was carried out in collaboration between all authors. Author KTA designed the study, procured the raw materials, was involved in the microbiological and chemical analyses and wrote the first draft of the manuscript. Author BSA was in charge of literature searches and statistical analyses.

Author SF was involved in the microbiological, chemical and statistical analyses of the study. All authors read and approved the final manuscript.

Article Information

DOI: $10.9734 / J A M B / 2017 / 33191$

Editor(s):

(1) Foluso O. Osunsanmi, Department of Biochemistry and Microbiology, University of Zululand, South Africa.

Reviewers:

(1) C. M. Narayanan, National Institute of Technology, Durgapur, India.

(2) Laila Hussein, National Research Center, Giza, Egypt.

(3) Clifford Nkemnaso Obi, College of Natural Sciences, Michael Okpara University of Agriculture, Umudike, Nigeria. Complete Peer review History: http://www.sciencedomain.org/review-history/19083

Original Research Article

Received $2^{\text {nd }}$ April 2017

Accepted $29^{\text {th }}$ April 2017

Published $16^{\text {th }}$ May 2017

\section{ABSTRACT}

Aim: This study investigated the effect of fermentation on nutrient and antinutrient contents of African bush mango (Irvingia gabonensis).

Methodology: Bush mango seeds were fermented for a period of five days. Microbiological contents, temperature, $\mathrm{pH}$ and total titratable acidity were monitored on daily basis while the proximate composition, mineral contents and the antinutrient contents of the unfermented and the fermented samples were determined.

Results: The bacteria isolated from seeds include Bacillus subtilis, Bacillus polymyxa, Lactobacillus fermentum, Enterococcus faecalis and Staphylococcus aureus while the fungal isolates were Aspergillus niger, Aspergillus flavus, Fusarium poae, Rhizopus stolonifer and Penicillium chrysogenum. Both bacterial and fungal counts increased throughout the fermentation period while temperature increased from $27.5^{\circ} \mathrm{C}$ to $30^{\circ} \mathrm{C}$ on the third day but decreased to $29.7^{\circ} \mathrm{C}$

${ }^{*}$ Corresponding author: E-mail: kehinde.adegbehingbe@aaua.edu.ng; 
at the end of the fermentation. The moisture, crude protein and the ash contents increased while crude fat, crude fibre and the carbohydrate contents reduced in the fermented seeds. Protein content increased from $8.48 \%$ to $10.39 \%$. Potassium and iron contents of the samples were found to reduce while phosphorus, manganese and sodium increased after the fermentation process. All the antinutrient contents that were determined reduced significantly after the fermentation process. Conclusion: Fermented bush mango seeds can be used to produce nutritious condiments if properly processed.

Keywords: African bush mango; legume; nutrient; antinutrient; fermentation.

\section{INTRODUCTION}

Fermented foods are palatable and wholesome foods prepared from raw, soaked, or heat-treated raw materials through the action of microorganisms. Fermented foods constitute an important part of our diet and are estimated to provide about $20-40 \%$ of human food supply [1]. Health benefits can also be got from fermented foods through the probiotic effects of the fermenting microorganisms. Fermentation also improves wholesomeness through improved digestibility and enrichment of food with essential nutrients (vitamins, proteins, and essential amino acids, fatty acid) [2]. It can also enhance bioavailability of food components through catabolism of the food anti-nutrients [3]. The metabolic activities of the fermenting organisms may result to the formation of inhibitory substances such as lactic acids, acetic acids, formic acids, propionic acids, ethanol, and bacteriocins often in combination, improving hygiene through inhibition and even elimination of food pathogens in such foods [4,5]. Quite a number of Bacillus and Lactobacillus species have been isolated from various fermented food condiments. Although yeasts and other bacteria are also seen, only part of them can be considered to play a substantial role in fermentation processes [6].

Seeds of legumes account for up to $80 \%$ of dietary protein and may be the only source of protein for some groups. Their cooked forms are eaten as meals while the fermented forms as condiments to enhance the flavors of foods [7]. Legume condiments can serve as a tasty complement to sauces and soups serving as substitutes for fish or meat. Fermented legumes have characteristic organoleptic properties, which probably are the most important factors attracting consumers [8]. Macronutrients in fermented legumes also enhance their food quality [9].

African bush mango (Irvingia gabonensis) tree belongs to family Irvingiaceae [10] and is found throughout the tropical forest of Africa. It is widely cultivated in central and Western Africa [11]. It is called bush mango or African mango because the trees bear mango-like fruits. The fruits are broadly ellipsoid and variable in size between 5$7.5 \mathrm{~cm}$ with a fleshy mesocarp surrounding a large seed and 3-6 cm long The green mature fruits turn yellowish when ripe [12]. In West Africa, bush mango trees top the list of non timber forest products being clamored for domestication, and it is fast becoming the tree of choice in agro-forestry practices [13]. Their flesh can either be pleasant and sweet (Irvingia gabonensis) or bitter (Irvingia wombolu) and inedible [14].

Because of its excellent nutritional value, the fruit is often used for preparing food dishes. The fruit pulp is juicy although the taste varies between sweet and bitter depending on the type and has been shown to have great industrial potentials ranging from the preparation of juices, jams and jellies to wine and soap making $[13,15]$. Bush mango is especially valued for their fat and protein rich kernels which can also serve as a sauce thickening agent [14]. The seeds are a good source of vitamins and minerals such as calcium, magnesium, potassium, sodium, phosphorus, and iron [16,17].

African bush mango can be used in the production of jam, flour and its pounded form is used as additives to meats and various vegetable dishes. Oil extracted from the kernel of bush mango is used for soap making, cosmetics and pharmaceuticals. It has also been reported that they are important in the treatment of diarrhoea and dysentery. It can also be used as a purgative, for gastrointestinal and liver conditions, for sterility, hernia and urethral discharge, and is considered to be a powerful aphrodisiac [18].

The objective of this work is to determine the effect of fermentation on the nutritional quality of African bush mango seeds based on the fact that no much work has been done on the fermentation of the seeds. 


\section{MATERIALS AND METHODS}

\subsection{Collection of Samples}

The African bush mango seeds were purchased from Okusa market Akungba-Akoko and brought to the Microbiology Laboratory of Adekunle Ajasin University, Akungba-Akoko, Nigeria for analyses.

\subsection{Fermentation of Bush Mango Seed Cotyledons}

Two hundred and fifty grams of the fresh and healthy African bush mango seed cotyledons were surface sterilized by dipping in $90 \%$ ethyl alcohol for $1 \mathrm{~min}$ and rinsed in several changes of sterile distilled water. The cotyledons were boiled for 20 minutes, allowed to cool and poured into a plastic container containing $500 \mathrm{ml}$ of sterile distilled water. The cotyledons were then allowed to ferment naturally for 5 days. The sample was prepared in triplicates.

\subsection{Isolation Procedure}

Microorganisms were isolated from the fermenting samples on daily basis for the five day fermentation period using standard methods. Plate count agar and nutrient agar were respectively used for enumerating and cultivating bacteria at $37^{\circ} \mathrm{C}$ for 24 hours while yeasts and fungi were cultivated with Sabauraud dextrose agar and potato dextrose agar respectively at $25^{\circ} \mathrm{C}$ for 72 to 96 hours. Pure isolates were got by repeated streaking on their respective media while the isolates were identified based on their cultural, morphological and biochemical characteristics using standard methods $[19,20]$.

\subsection{Determination of Temperature, $\mathrm{pH}$ and Total Titratable Acidity}

The temperature, $\mathrm{pH}$ and Total titratable acidity of the fermenting sample were monitored during fermentation period on daily basis. The temperature of the samples was determined by aseptically inserting a thermometer sterilised with $75 \%$ ethanol into the fermenting sample. The container was covered immediately and left for about five minutes before the thermometer was aseptically removed from the container. The $\mathrm{pH}$ of the sample was determined by homogenizing $2 \mathrm{~g}$ of the sample with $20 \mathrm{ml}$ of distilled water. The digital $\mathrm{pH}$ meter (Crison Basic Model 20) used was standardized with a buffer solution of buffer $6.9,4.2$ and 9.0 before use.
Total titratable acidity (TTA) was determined by grinding $2 \mathrm{~g}$ of the sample and mixing it $25 \mathrm{ml}$ of distilled water in a beaker. This was titrated against $0.4 \mathrm{ml}$ of sodium hydroxide $(\mathrm{NaOH})$ with the addition of 4 drops of phenolphthalein as an indicator [21].

\subsection{Food Proximate Composition and Mineral Determination}

Food Proximate composition of the samples was carried out according to A.O.A.C. [21]. Iron, calcium, potassium, sodium and magnesium contents of the samples were determined using atomic absorption spectrophotometer (Perkin Elmer 500 and Varian AA 475).

\subsection{Anti-Nutrient Determination}

The raw and fermented samples were analyzed for the presence of saponins, cyanide, phytate, oxalate and tannin [22-25].

\section{RESULTS}

\subsection{Bacterial Counts}

Fourteen bacteria and ten fungi were isolated during of the fermentation of African bush mango seeds. The bacteria include Bacillus subtilis, Bacillus polymyxa, Lactobacillus fermentum, Enterococcus faecalis and Staphylococcus aureus while the fungi were Aspergillus niger, A. flavus, Fusarium poae, Rhizopus stolonifer and Penicillium chrysogenum. The Bacillus species were isolated throughout the period while Lactobacillus and Aspergillus niger were present throughout the fermentation period while Rhizopus and Lactobacillus species were isolated after 24 hours from the samples till the 72 hours and the end of the fermentation period respectively. Penicillium chrysogenum and Rhizopus species were isolated after 48 hours of the fermentation process. Enterococcus faecalis and Aspergilus flavus were isolated on the first and second days while Staphylococcus aureus, Fusarium and Aspergillus niger were isolated at the first two days of fermentation process respectively (Table 1 ).

Bacterial counts which increased from $3.6 \times 10^{4}$ $\mathrm{cfu} / \mathrm{ml}$ to $4.5 \times 10^{7} \mathrm{cfu} / \mathrm{ml}$ at 72 hours of the fermentation to $5.10 \times 10^{6} \mathrm{cfu} / \mathrm{ml}$ at 72 hours of the fermentation which was followed with a sharp decrease to $2.8 \times 10^{6} \mathrm{cfu} / \mathrm{ml}$ at 96 hours and later slightly increased to $2.9 \times 10^{6} \mathrm{cfu} / \mathrm{ml}$ at 120 hours at the end fermentation. Fungal counts also increased from $1.8 \times 10^{3} \mathrm{sfu} / \mathrm{ml}$ to $8.4 \times 10^{4} \mathrm{sfu} / \mathrm{ml}$ at the end of the fermentation period (Table 2). 
Table 1. Occurrence of microorganisms during the fermentation of African bush mango seeds

\begin{tabular}{lllcll}
\hline Isolates & \multicolumn{5}{c}{ Period (days) } \\
\cline { 2 - 6 } & $\mathbf{1}$ & $\mathbf{2}$ & $\mathbf{3}$ & $\mathbf{4}$ & $\mathbf{5}$ \\
\hline Bacillus polymyxa & + & + & + & + & + \\
Bacillus subtilis & + & + & + & + & + \\
Lactobacillus fermentum & - & + & + & + & + \\
Enterococcus faecalis & + & - & - & - & - \\
Staphylococcus aureus & + & + & - & - & - \\
Penicillium chrysogenum & - & + & + & + & + \\
Rhizopus stolonifer & - & + & + & + & - \\
Fusarium poae & + & + & - & - & - \\
Aspergillus flavus & - & + & - & - & - \\
Aspergillus niger & + & + & - & - & - \\
\hline
\end{tabular}

Table 2. Change in microbial counts of fermenting African bush mango seeds

\begin{tabular}{lllllll}
\hline Microbial counts & \multicolumn{5}{c}{ Fermentation period (hours) } \\
\cline { 2 - 7 } & $\mathbf{0}$ & $\mathbf{2 4}$ & $\mathbf{4 8}$ & $\mathbf{7 2}$ & $\mathbf{9 6}$ & $\mathbf{1 2 0}$ \\
\hline Bacterial counts $(\mathrm{cfu} / \mathrm{ml})$ & $3.6 \times 10^{4}$ & $1.2 \times 10^{5}$ & $4.5 \times 10^{6}$ & $4.5 \times 10^{7}$ & $2.8 \times 10^{6}$ & $2.9 \times 10^{7}$ \\
Fungal counts $(\mathrm{sfu} / \mathrm{ml})$ & $1.8 \times 10^{3}$ & $2.0 \times 10^{3}$ & $4.0 \times 10^{3}$ & $3.4 \times 10^{4}$ & $5.2 \times 10^{4}$ & $8.4 \times 10^{4}$ \\
\hline \multicolumn{6}{c}{ Values are means of triplicate determination }
\end{tabular}

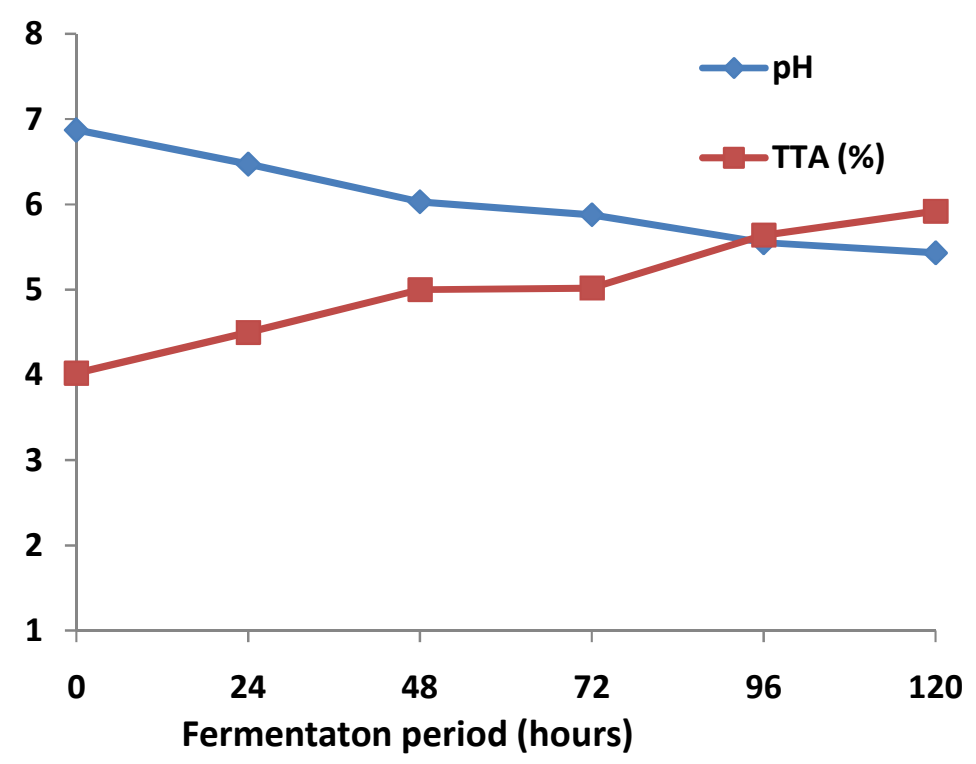

Fig. 1. The $\mathrm{pH}$ and the total titratable acidity of the fermenting African bush mango seeds

\section{$3.2 \mathrm{pH}$ and Total Titratable Acidities (TTA) of the Fermenting African Bush Mango Seeds}

The $\mathrm{pH}$ of the samples decreased throughout the fermentation period from 6.87 to 5.43 while the TTA increased from $4.02 \%$ to $5.97 \%$ (Fig. 1)

\subsection{Temperature of the Fermenting African Bush Mango Seeds}

The temperature of the fermenting sample increased from $27.5^{\circ} \mathrm{C}$ to $30.5^{\circ} \mathrm{C}$ on the $3^{\text {rd }}$ day and later reduced to $29.7^{\circ} \mathrm{C}$ at the end of the fermentation period (Fig. 2) 


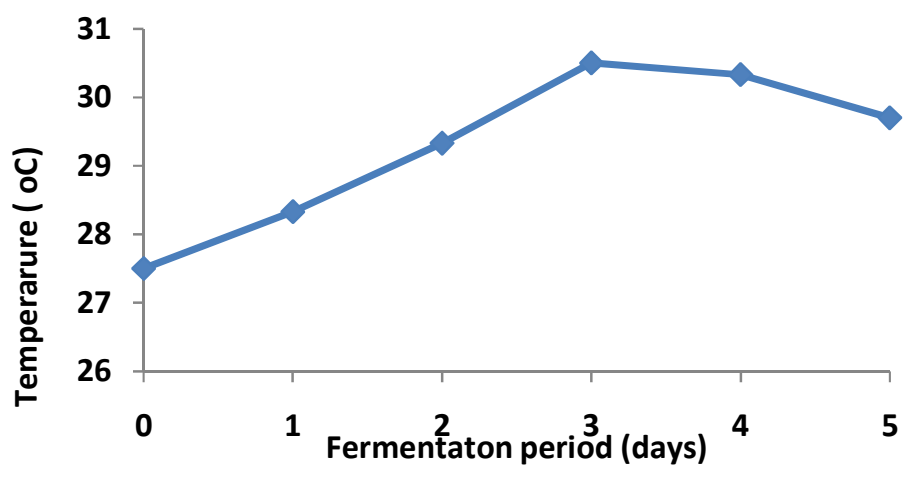

Fig. 2. The temperature of fermenting African bush mango seeds

\subsection{Proximate Composition of the Fermenting African Bush Mango Seeds}

The results of proximate composition of the unfermented and the fermented samples were shown in Fig. 3. The contents of the proximate composition that increased after fermentation were the moisture content $(7.23-9.43) \%$, crude protein $(8.48-10.39) \%$ and the ash $(3.37$ $4.13) \%$ while reductions were observed in crude fat $(46.28-43.05) \%$, crude fibre $(2.61-1.87) \%$ and the carbohydrate ( $32.03-31.13) \%$ contents of fermented bush mango seeds (Fig. 3 ).

\subsection{Anti-Nutrient Contents of the Fermenting African Bush Mango Seeds}

All the antinutrient contents that were determined in the seeds reduced significantly after fermentation (Table 3). Tannin reduced from $173.53 \mathrm{mg} / 100 \mathrm{~g}$ to $47.42 \mathrm{mg} / 100 \mathrm{~g}$, oxalate from $373.64 \mathrm{mg} / 100 \mathrm{~g}$ to $123.35 \mathrm{mg} / 100 \mathrm{~g}$, cyanide from $8.52 \mathrm{mg} / 100 \mathrm{~g}$ to $3.27 \mathrm{mg} / 100 \mathrm{~g}$, saponin from $13.73 \mathrm{mg} / 100 \mathrm{~g}$ to $4.66 \mathrm{mg} / 100 \mathrm{~g}$ and Phytate from $92.43 \mathrm{mg} / 100 \mathrm{~g}$ to 31.62 $\mathrm{mg} / 100 \mathrm{~g}$.

\subsection{Mineral Composition of Fermenting African Bush Mango Seeds}

Fluctuations were observed in the mineral contents of the seeds after fermentation (Table 4). Increases were observed in sodium $(21.03-23.50) p p m$, calcium (96.06 - 98.35)ppm and magnesium $(65.30$ - 65.64)ppm but not significantly different while significant reductions were found potassium (187.07 - 167.85)ppm and iron $(1.69-0.69)$ ppm of the fermented sample.

\section{DISCUSSION}

The kind and number of microorganisms on any substrate depend on the nutritional composition supporting their growth. Bacillus species have been isolated in many fermented foods. Adegbehingbe et al. [26] isolated Bacillus polymyxa, $B$. subtilis while fermenting lima beans seeds. Staphylococcus and Bacillus species were also isolated from Parkia biglobosa during its fermentation for Iru production [27]. Isolation of similar fungi by Aboloma and Ogunsola [28] on dry bush mango seeds is an indication that the fungi could be natural microflora of the seeds. Ojokoh [29] isolated Aspergillus and Rhizopus sp. while fermenting mango peels. The disappearance of Enterococcus faecalis, Staphylococcus aureus, Fusarium poae and Aspergillus species at the early stages of the fermentation could be due to their inability to withstand the antimicrobial substances produced by the predominant microorganisms in the substrates [26]. The increases in the microbial loads observed in this work as the fermentation progressed had been reported by many researchers in some fermented cereal and legume products. This had been majorly attributed to the ability fermenting microorganisms to metabolise the substrates thereby enhancing their proliferation [26,30-32].

The reduction in $\mathrm{pH}$ and subsequent increase in titratable acidity as the fermentation progressed could be due to the organic acid synthesis by the fermenting microorganisms such as Lactobacillus species [33]. Similar findings were also reported by Mbata et al. [34] while fermenting maize fortified with bambara nut. The initial increase in temperature in this research could be due to the metabolism of the substrate by the fermenting microorganisms [27]. 


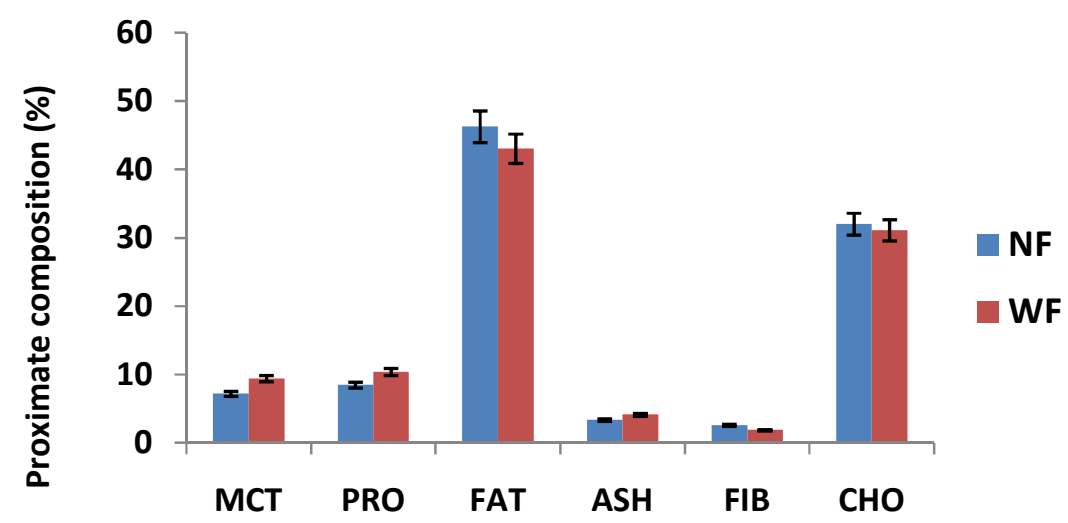

Fig. 3. The proximate composition of the unfermented and fermented African bush mango seeds

Key: NF = Unfermented African bush mango, $W F=$ Fermented African bush mango, MCT = Moisture content, $P R O=$ Protein content, $F I B=$ Fibre content,$C H O=$ Carbohydrate content

Table 3. The antinutrient contents of the unfermented and fermented African bush mango seeds

\begin{tabular}{llllll}
\hline Samples & $\begin{array}{l}\text { Tannin } \\
(\mathbf{m g} / 100 \mathrm{~g})\end{array}$ & $\begin{array}{l}\text { Oxalate } \\
(\mathbf{m g} / 100 \mathrm{~g})\end{array}$ & $\begin{array}{l}\text { Cyanide } \\
(\mathbf{m g} / \mathbf{1 0 0} \mathbf{g})\end{array}$ & $\begin{array}{l}\text { Saponin } \\
(\mathbf{m g} / 100 \mathrm{~g})\end{array}$ & $\begin{array}{l}\text { Phytate } \\
(\mathbf{m g} / 100 \mathrm{~g})\end{array}$ \\
\hline Unfermented & $173.52^{\mathrm{a}}$ & $373.64^{\mathrm{a}}$ & $8.52^{\mathrm{a}}$ & $13.73^{\mathrm{a}}$ & $92.43^{\mathrm{a}}$ \\
Fermented & $47.42^{\mathrm{b}}$ & $123.85^{\mathrm{b}}$ & $3.27^{\mathrm{b}}$ & $4.66^{\mathrm{b}}$ & $31.62^{\mathrm{b}}$ \\
\hline
\end{tabular}

Values are means of triplicate determinations. Values with the same superscript down the column are not significantly different $(p<0.05)$

Table 4. Mineral content of fermented and unfermented African bush mango seeds (ppm)

\begin{tabular}{lll}
\hline Parameters & Unfermented & Fermented \\
\hline Sodium (Na) & $21.03^{\mathrm{a}}$ & $23.50^{\mathrm{a}}$ \\
Potassium (K) & $187.07^{\mathrm{a}}$ & $167.85^{\mathrm{b}}$ \\
Calcium (Ca) & $92.06^{\mathrm{ab}}$ & $98.35^{\mathrm{a}}$ \\
Magnesium(Mg) & $65.30^{\mathrm{a}}$ & $65.64^{\mathrm{a}}$ \\
Iron (Fe) & $1.69^{\mathrm{a}}$ & $0.69^{\mathrm{b}}$ \\
\hline
\end{tabular}

The moisture content which increased in the fermented African mango seeds could be attributed to the secretion of free water molecules due to the activities of the fermenting microorganisms in the medium [32]. The result of moisture content was found to be lower when compared to other fermented legumes such as Canavalia ensiformis (29.8\%) [35] and African locust bean (and 30.87\%) [31]. The differences could be due to addition of water during processing or the moisture contents were determined using wet method. The increase in protein contents of some fermented seeds had been reported by different researchers [26,36]. The high protein contents observed in the fermented sample could be as a result of the proliferation of the microbial biomass during fermentation or their ability (microorganisms) to synthesize amino acids and proteins [17,37]. The reduction in fat contents after fermentation conforms to Enuijugha [2000] while fermenting African oil bean seeds. The decrease in fat content might be due to production of lipolytic enzymes by the fermenting organisms which hydrolyzed fats in the sample to glycerol and fatty acids [38].

An increase in ash content may be due to the microbial degradation of antinutrient contents in the seeds during fermentation. This infers that more mineral elements in the fermented sample. However, Adegbehingbe et al. [26] reported reduction in ash contents while fermenting lima bean seeds beans which they attributed to the leaching of soluble inorganic salts into the processing water during fermentation or they were been metabolized by the fermenting microorganisms. The reduction in the total carbohydrate content might be attributed to the saccharolytic enzymes secreted by the fermenting microorganisms and utilization of some of the sugars needed for their growth and metabolism. Odetokun [39] reported a decrease in the carbohydrate content of fermented cereal and legume blend. This result was also in 
agreement with Omodara and Olowolafe [31] while fermenting African locust bean and soy bean.

The reduction observed in all the antinutrient contents of African bush mango seeds after fermentation had been reported in many fermented legumes $[1,40,41]$. The reduction in the antinutrient contents might be attributed to the hydrolytic activities of the fermenting microorganisms and leaching into the fermentation vessels $[26,42]$. Some lactic acid bacteria and fungi such as Rhizopus oligosporus have known to secrete phytases which could degrade phytate to considerable levels $[43,44]$. The significant reductions in the antinutrient contents of the sample are welcome development because the minerals and other nutrients bound to them are more readily available $[26,43,44]$.

The low levels of iron were recorded for the fermented samples which were lower than that of the unfermented raw sample. The levels obtained still compared favourably with the values obtained by Aletor and Ojelabi [45] in their analysis of some traditional Nigerian snacks. The increase in the levels of potassium in the samples fell within the dietary limit recommended by World Health Organization. There were reductions in the levels of sodium in the samples. The reduction in these minerals could be as a result of their utilization by the fermenting microorganisms [46].

\section{CONCLUSION AND RECOMMENDA- TION}

The results of this experiment show that bush mango seed cotyledons have nutritional benefits which can be enhanced when fermented. Fermentation helps to increase the protein and ash content of the seeds thus improving its nutritional quality. Further research on the seeds should focus on the optimization of the fermentation conditions as well as effect of starter cultures on the nutritional quality of the seeds.

\section{COMPETING INTERESTS}

Authors have declared that no competing interests exist.

\section{REFERENCES}

1. Fagbemi TN, Oshodi AA, Ipinmoroti KO. Processing effects on some antinutritional factors and in vitro multienzyme protein digestibility (IVPD) of three tropical seeds: breadnut (Artocarpus altilis), cashewnut (Anacardium occidentale) and fluted pumpkin (Telfairia occidentalis). Pak. J. Nutri. 2005;4:250-256.

2. Van Boekel M, Fogliano V, Pellegrini N, Stanon C, Scholz G, Lalljie S, Somoza V, Knorr D, Jasti PS, Eisenbrand G. A review on the beneficial aspect of food processing. J. Nutri. Food. 2010;54:12151247.

3. Steinkraus $\mathrm{KH}$. Origin and history of food fermentation. In: (Eds. Hui YH, MeunierGoddik L, Hansen AS, Josephen J, Nip WK, Stanfield PS, Toldra F.). Handbook of food and beverage fermentation technology. CRC Press. 2004;1-9.

4. Caplice E, Fitzerald GF. Food fermentation, roles of microorganisms in food production and preservation. Int. J. Food Microbiol. 1999;50:131-149.

5. Adams M, Mitchell R. Fermentation and pathogen control: A risk assessment approach. Int. J. Food Microbiol. 2002; 79:75-83.

6. Achi OK. Microorganisms associated with natural fermentation of Prosopis africana seeds for the production of okpiye. PI. Foods. Human Nutri. 1991;42:297-304.

7. Achi OK. The upgrading of traditional fermented foods through biotechnology. Afr. J. Biotechnol. 2005;4:375-380.

8. Dakwa S, Sakyi-Dawson E, Diako C, Annan NT, Amoa-Awua WK. Effect on the fermentation of soybeans into Dawadawa (Soy-dawadawa). Int. J. Food Microbiol. 2005;104:69-82.

9. Ogbonna DN, Sokari TG, Achinewhu SC. Development of an owoh-type product from African yam beans (Sphenostylis stenocarpa) Hoechst ex. A. Rich) Harms) by solid substrate fermentation. Plant Foods Human Nutri. 2001;56:183-194.

10. Lesley L, Brown N. Bush mango (Irvingia gabonensis and Irvingia wombolu). In key non timber forest products of central Africa: state of the knowledge (Eds. Clark LE, Sunderland. CH). 2004;15-35.

11. Kengni E, Kengue J, Ebenezer EBK, Tabuna $\mathrm{H}$. Irvingia gabonensis, Irvingia wombolu, bush mango. Conservation and sustainable uses of Genetic Resource of priority food tree spices in sun-Sahara Africa. Bioversity International, Rome, Italy; 2011. 
12. Leakey $R$, Schrecheriberg $K$, Tchoundjev $Z$. The participatory domestication of West African indigenous fruits. Int. Forest. Rev. 2003;5:338-347.

13. Leakey RRB, Greenwell $P$, Hall MN, Atangana AR, Usoro C, Anegbeh PO, Foundoun JM, Tchoundjeu $Z$. Domestication of Irvingai gabonensis: Tree to tree variation of food thickening properties and in fat and protein contents of dika nuts. J. Food Chem. 2005;90:365378.

14. Matos L, Nzikou JM, Matouba E, PandzouYembe VN, Mapepoulou TG, Linder M, Desobry S. Studies of Irvingia gabonensis seeds kernels: Oil technological applications. Pak. J. Nutri. 2009;8:151-157.

15. Etebu E. Postharvest pathology and phytochemicals of Irvingia gabonensis fruits and wastes. J. Agric. Sci. Res. 2012; 2(6):285-294.

16. Onimawo IA, Oteno F, Orokpo G, Akubor $\mathrm{PI}$. Phytochemical and nutrients evaluation of African bush mango (Irvingia gabonensis). seeds and pulp. Plant Foods Human Nutri. 2003;58:1-6.

17. Ekpe OO, Umoh IB, Eka OU. Effect of a typical rural processing method on the proximate composition and amino acid profile of bush mango seeds lirvingia gabonensis). Afric. J. Food. Agric. Nutri. Dev. 2007;7:(1):1-12.

18. Ngondi JL, Oben JE, Minka SR. The effect of Irvingia gabonensis seeds on body weight and blood lipids of obese subjects in Cameroon. Lipids Health Disease. 2009; 4:12-15.

19. Buchanans RE, Gibbons NE. Bergey's Manual of Determinative Bacteriology. $8^{\text {th }}$ Edition. Williams and Wilkins company, Baltimore. 1974;520-644.

20. Alexopoulous CJ, Mims CW, Blackwell MB. Introductory mycology. John Wiley and Sons; 1996.

ISBN 0-471-52229-5

21. AOAC. Official Methods of analysis. Association of official analytical chemists. $16^{\text {th }}$ Edition. Washington D.C; 1995.

22. Egwaikhide PA, Okeniyi SO, Gimba CO. Screening for antimicrobial activity and phytochemical constituents of some Nigerian medicinal plants. J. Med. Plant Res. 2009;3(12):1088-1091.

23. Bradbury MG, Egen SV, Bradbury JH. Determination of all forms of cyanogens in cassava roots and cassava products using picrate paperkits. J. Sci. Food Agric. 1999; 79:593-601.

24. Lucas GM, Markakes P. Phytic acid and other phosphorus compounds of nevy bean (Phaseolos vulgaris). J. Agric. Food Chemi. 1975;23:13-15.

25. Van-der-poel AFB. Effect of processing on anti-nutritional factor and protein nutritional value of dry beans. Anim. Feed Sci. Technol. 1990;2:179-208.

26. Adegbehingbe KT, Adetuyi FC, Akinyosoye FA. Effect of fermentation on nutrient and antinutrient contents of ground-cooked lima bean (Phaseolus lunatus) seeds using Bacillus subtilis and Bacillus pumilus. Brit. Microbiol. Res. J. 2014;4(11):1285-1298.

27. Oladunmoye MK. Effect of fermentation on nutrient enrichment of locust beans (Parkia bioglobosa). Res. J. Microbiol. 2007;185189.

28. Aboloma RI, Ogunbusola EM. Fungi associated with Irvingia gabonensis (ogbono) and Colocynthis citrullus (egusi) seeds sold in markets in Ado-Ekiti, Ekiti State Nigeria. J. Nat. Product Plant Res. 2012;2:423-426.

29. Ojokoh AO. Effect o fermentation on the chemical composition of mango (Mangifera indica) peels. Afric. J. Biotechnol. 2007; 6:1979-1981.

30. Adegbehingbe KT. Fermented sprouted and unsprouted maize for ogi production. Int. J. Adv. Res. 2013;1(10):428-434.

31. Omodara TR, Olowomofe TO. Effects of fermentation on the nutritional quality of African locust bean and soybean. Inter. Sci. Res. 2015;4(1):1069-1071.

32. Ojokoh AO, Abiola AB, Lawal RT, Changes in nutrient and anti-nutrient composition of popcorn and groundnut composite flour subjected to solid substrate fermentation. Afric. J. Agric. Res. 2012;3439-3445.

33. Ojokoh AO, Daramola MD. Evaluation of lima beans flour fermented with Lactobacillus species as a probiotic food. Afr. J. Food Sci. 2012;3:352-361.

34. Mbata TI, Ikenebomeh MJ, Ezeibe S. Evaluation of mineral content and functional properties of fermented maize (Zea mays) flour blend blended with Bambara groundnut (Vigna subterranean L.). Afr. J. Food Sci. 2009; 13(4):107-112. 
35. Doss A, Pugalenthi $M$, Vadivel VD, Subhashini G, Anitha-Subash R. Effects of processing technique on the traditional composition and antinutrients content of under-utilized food legume Canavalia ensiformis L.DC. Int. Food Res. J. 2011; 18(3):965-970.

36. Ojokoh AO, Wei Y. Effect of fermentation on chemical composition and nutritional quality of extruded and fermented soya products. Int. J. Food Eng. 2011;7(4).

37. Oseni OA, Ekperigin M. Studies on biochemical changes in maize wastes: Fermented with Aspergillus niger. Biokemistri. 2010;19(2):75-79.

38. Oyarekua MA. Biochemical and microbiological changes during the production of fermented pigeon pea (Cajanus cajan) flour. Afr. J. Food Sci. Technol. 2011;2(10):223-231.

39. Odetokun SM. Effect of fermentation on some physiochemical properties, antinutrients and in vitro multienzyme digestibility of selected legumes. Ph.D Thesis. The Federal University of Technology: Akure, Nigeria. 2000;148.

40. Effiong OO, Umoren, UE. Effects of multiprocessing techniques on the chemical composition of horse eye beans (Mucuna urens). Asian J. Anim. Sci. 2011; 5(5):340-248.
41. Olagunju Al, Ifesan BOT. Changes in nutrient and antinutritional contents of sesame seeds during fermentation. J. Microbiol. Biotechnol. Food Sci. 2013;2(6): 2407-2410.

42. Ojokoh AO. Effect of fermentation on the nutritional qualities of roselle (Hibiscus sabdariffa Linn) calyx Ph.D Thesis, The Federal University of Technology, Akure, Nigeria; 2005.

43. Chelule PK, Mbongwa HP, Carries S, Gqaleni N. Lactic acid fermentation improves the quality of Amahewu, a traditional South African maize-based porridge. Food Chem. 2010;122(3):656661.

44. Greiner MAR, Jany KD. Purification and characterization of two intracellular phytases from the Tempeh fungus Rhizopus oligosporus. J. Food Biochem. 2011;35:213-227.

45. Aletor O, Ojelabi A. Comparative evaluation of the nutritive and functional attributes of some traditional Nigerian snacks and oil seed cakes. Pak. J. Nutri. 2007;6:99-103.

46. Aderiye BJ. Ogunjobi AA. Fermentation of yam, microbiology and sensory evaluation of cooked fermented yam tissues. Int. J. Plant Food Human Nutri. 1998;52:49-54.

(c) 2017 Adegbehingbe et al.; This is an Open Access article distributed under the terms of the Creative Commons Attribution License (http://creativecommons.org/licenses/by/4.0), which permits unrestricted use, distribution, and reproduction in any medium, provided the original work is properly cited.

Peer-review history:

The peer review history for this paper can be accessed here: http://sciencedomain.org/review-history/19083 